\title{
Macroeconomic and Financial Stability in a Monetary Union: The Case of Lithuania*
}

\author{
Margarita Rubio \\ Mariarosaria Comunale \\ University of Nottingham ${ }^{\dagger}$ \\ Bank of Lithuania ${ }^{\ddagger}$
}

March 2017

\begin{abstract}
In this paper, we study the implications for macroeconomic and financial stability of macroprudential policies in a monetary union. With this purpose, we develop a two-country monetary union new Keynesian general equilibrium model with housing and collateral constraints, to be calibrated for Lithuania and the rest of the euro area. We consider two different scenarios for macroprudential policies: one in which the ECB extends its goals to also include financial stability and a second one in which a national macroprudential authority uses the loan-to-value ratio (LTV) as an instrument. Results show that both rules are effective in bringing a more stable financial system in both countries, and especially in Lithuania. This is because the financial sector in this country is more sensitive to shocks. We find that an extended Taylor rule is indeed effective in reducing the volatility of credit but it comes with a cost in terms of higher inflation volatility. The simple LTV rule on its side, does not compromise the objective of monetary policy. This reinforces the "Tinbergen principle" which argues that there should be two different instruments when there are two different policy goals.
\end{abstract}

Keywords: Macroprudential policy, housing market, LTV, monetary union, financial stability

JEL Codes: E32, E44, F36

\footnotetext{
${ }^{*}$ The authors would like to aknowledge the help of Aurelijus Dabušinskas, Marius Jurgilas, Darius Kulikauskas, Nijolè Valinskytė, Julius Stakėnas, Mihnea Constantinescu, Karsten Staehr, Michael Funke, Aaro Hazak, Zsuzsanna Hosszú, Tomas Reichenbachas and Tomas Ramanauskas for very useful discussions. Special thanks to the attendants of the Conference of the Czech National Bank and the Institute of Economic Studies "Challenges for Financial Stability in Europe." We would also like to thank the seminar participants at the Bank of Lithuania for their comments. Part of this project has been undertaken while Margarita Rubio was a visiting researcher at the Central Bank of Lithuania. She would like to thank them for their support and hospitality. All errors are ours. The conclusions expressed are those of the authors and do not necessarily represent the official views of the Bank of Lithuania.

${ }^{\dagger}$ University Park, NG7 2RD Nottingham, UK. E-mail: margarita.rubio@nottingham.ac.uk.

${ }^{\ddagger}$ Totoriu g. 4, LT-01121, Vilnius, Lithuania. E-mail: mcomunale@lb.lt
} 
"We will maintain a clear separation of objectives between the macro-prudential policy framework and monetary policy and a clear hierarchy, with price stability remaining the ECB's overall primary objective. But we are very much aware that both policies may interact (...) Many of these questions are yet to be fully explored and we have to acknowledge that the macro-prudential policy framework is still in its infancy. We are in a learning process (...) Overall, I am optimistic that macro-prudential policies, if properly coordinated at the European level, will strengthen our defences against future financial instability in the euro area, while also addressing some of the side effects that come from a single monetary policy." Speech by Mario Draghi, at the Symposium on Financial Stability and the Role of Central Banks, 27 February 2014

\section{Introduction}

Lithuania, as a new member of the euro area, has to implement its macroprudential policies in the context of this new economic setting, by interacting with the other monetary union members, that indeed share the same monetary policy. The Bank of Lithuania pursues macroprudential policy at the national level and monitors, assesses, and acts to limit the macroprudential risk for the stability of the domestic financial system; in doing so, it has the possibility to cooperate with the ECB and other national and international institutions.

Macroprudential implementation is particularly relevant in the context of monetary unions, especially if they are non-optimal monetary areas like the euro area. There is good evidence that both business and financial cycles are not perfectly synchronized among members and that there are important cross-country structural differences. ${ }^{1}$ For instance, there are some particularities in the Lithuanian housing markets that make it different from its euro area partners. One of these differences regards mortgage contracts. Housing loans (and loans to non-financial corporations, NFCs) in Lithuania are almost exclusively made at variable interest rates (which are set for fixed periods, e.g. of up to 1 year), which are quick to respond to changes in borrowing costs in the financial markets. ${ }^{2}$ In the beginning of 2013, about 70 per cent of new loans to households were issued at flexible interest rates. In 2014 and 2015, the proportion increased to more than 80 per cent (in 2015 the share of flexible rate loans, for both

\footnotetext{
${ }^{1}$ See for instance Comunale and Hessel (2014), for an analysis of financial and business cycles in the euro area. See Comunale (2017), for a study on synchronicity of cycles within countries and structural aspects of mortgage markets and housing in the EU. For an analysis of the cross-country synchronization, see Mink et al. (2012) and Samarina et al. (2015).

${ }^{2}$ See Karmaziene and Varanauskiene (2014).
} 
households and NFCs, reached 90 per cent). ${ }^{3}$ In the big countries of the euro area, however, the majority of households take mortgages at a fixed rate. ${ }^{4}$ For France and Germany, the ratio of flexible-rate loans is pretty low, around 12 per cent and 15 per cent respectively, while in Spain it reaches 82 per cent. This high heterogeneity is reflected in an average percentage of variable-rate mortgages in the old members of the euro area of 45 per cent (the correspective percentage of fixed-rate loans is therefore 55 per cent). The percentage of flexible rate loans is even lower if we take into account euro area with 19 members. Also, the amount of consolidated debt (over GDP) of both households and NFCs is quite heterogeneous across the euro area. Lithuanians experienced low values in both cases, even if debt levels increased rapidly in the period 2006-2009, especially for NFCs (83\% of GDP at the peak on an average of $64 \%$ in the last decade and 55\% in 2015). In Table A.1 in the Appendix, we show these differences in housing and mortgage markets across the euro area member states.

In this context, the single monetary policy cannot be used to stabilize the economy of a particular member when it is shocked by an asymmetric disturbance or when the reaction to a common disturbance is different due to the structural characteristics of that member state. Therefore, different countries may have limited scope to influence their domestic macroeconomic conditions. The behavior of financial cycles and related build-ups of systemic risks often remain local in nature, even if spillovers and global factors may occur. Thus, macroprudential policy is especially important in a currency union such as the euro area, given the absence of country-specific monetary policy. In this setting, there would be a role for the macroprudential policy to complement monetary policy, especially if it is conducted at a national level. Most of macroprudential tools can have an impact on inflation and activity. Thus, it could happen that macroprudential policies reinforce the monetary policy decisions, but also that they counteract each other. Therefore, it is crucial to assess the effects of policies across member states.

It is clear now that preventing and mitigating systemic risks to financial stability has become an explicit policy objective. However, the stance of macroprudential policy must reflect financial cycles and structures, which, as already stated, can differ markedly across member states. The objectives of monetary and macroprudential policy are distinct, but may complement each other. The objective of monetary policy is typically price stability although it may be extended to include financial stability, given that price stability cannot be maintained in an unstable financial system. Equally, financial stability, the objective of macroprudential policy, cannot be maintained when inflation is out of control.

\footnotetext{
${ }^{3}$ Data from the website of the Bank of Lithuania (Statistics).

${ }^{4}$ See Ehrmann and Ziegelmeyer (2014) on data from ECB. They report the share of flexible-rate mortgages among the oldest active mortgages related to the household main residence.
} 
Therefore, monetary policy can reinforce financial stability but it can also have undesirable side effects on financial stability. For example, low policy rates, consistent with the pursuit of price stability, may lead to asset price bubbles that could pose risks to financial stability. Macroprudential policy can address such risks with instruments that are more targeted than monetary policy instruments. Ultimately, it is necessary to find a policy mix that addresses financial stability without compromising monetary policy objectives.

In the European Union (EU), the European Systemic Risk Board (ESRB) is the main body responsible for monitoring macroprudential policies, although each country can implement its own policy. That is, macroprudential policies are implemented at a national level, but within a system of central supervision. However, the ECB could also include among its objectives to safeguard financial stability. In this policy framework, it is important to find the right toolkit of national macroeconomic policies in a monetary union that, necessarily, applies the same monetary policy among all its members. Thus, it is necessary to stabilize the financial cycle and to avoid financial divergences to arise in the euro area, without compromising real business cycle convergence. Therefore, country specific macroprudential policies will have an important role to play in the euro area in cooperation with ECB policy.

In this paper, we study these issues taking as an example the case in Lithuania. Now that Lithuania is part of the euro area, the question is how to correctly implement policies to promote financial stability, in accordance with the other members. The economy of Lithuania has suffered from the same financial stability problems stemming from the crisis as some other countries of the euro area. And it has in fact fully recovered in terms of economic activity. One of the intermediate objectives that the Bank of Lithuania has set is to mitigate excessive credit growth and too high leverage.

We aim at illustrating how macroprudential policies could be implemented in Lithuania and in the rest of the euro area. We propose the implementation of a macroprudential tool, based on the loan-to-value ratio $(\mathrm{LTV})^{5}$, that acts countercyclically. ${ }^{6}$ We compare the effects of this rule with an extended Taylor rule in which the ECB extends its objectives to also take care of financial stability. The basic modelling setup constitutes a two-country new Keynesian DSGE model with financial frictions. In each country,

\footnotetext{
${ }^{5}$ In our model, the LTV ratio will be calibrated to match the average (market) LTV in steady state. However the market LTV can vary depending on economic conditions and it may be different with respect to the imposed LTV cap set by authority. When the LTV cap is high, the collateral constraint is less tight. And, since the constraint in this model is binding, borrowers will borrow as much as they are allowed to. Lowering the LTV tightens the constraint and therefore restricts the loans that borrowers can obtain.

${ }^{6}$ Here we follow Angelini et al. (2014) in which they assume that the loss function in the economy also contains financial variables. Therefore, we use it as a proxy for financial stability, which is seen as the actual aim of macroprudential policy (Galati and Moessner, 2011).
} 
there is a group of individuals that are credit constrained and need housing collateral to obtain loans. Countries trade goods, and savers in each country have access to foreign assets. Within this setting, we study the macroeconomic and financial stability effects of macroprudential policies in Lithuania, in the context of the euro area. As a macroprudential tool, we propose a decentralized rule for the LTV which responds to national deviations in credit from its steady state. We also include the common monetary policy with a Taylor rule, consistent with the ECB target of price stability, with interest-rate smoothing for interest-rate setting by a single central bank. We then extend the Taylor rule to also respond to union credit deviations from its steady state.

Results show that in Lithuania, shocks are transmitted in a stronger way given variable rates in this country, higher mortgage debt and LTVs. However, macroprudential policies are successful at mitigating the effects on shocks on credit growth. We also find that both rules are effective in terms of reducing the volatility of borrowing and therefore in bringing a more stable financial system, the goal of macroprudential policies. However, the macroprudential Taylor rule seems to be more effective for this purpose in both countries. Nevertheless, even though this rule is very effective in reducing the volatility of credit, it comes with a cost in terms of inflation volatility. When using the interest rate as the only instrument both for monetary and macroprudential policy, there is a trade-off between stabilizing the financial system and keeping prices stable, which should be the primary goal of monetary policy. The LTV rule, although not as effective as the extended Taylor rule, does not compromise the objective of monetary policy. This reinforces the so-called "Tinbergen principle," which argues that there should be two different instruments when there are two different policy goals. We confirm the superiority of the dual regime in terms of welfare, in line with the recent literature (Carrillo et al., 2016).

The paper is organized as follows: Section 2 briefly addresses our main contribution, linking it to the recent literature. Section 3 describes the model. Section 4 presents the parameter values. Section 5 presents the dynamics of the model. Section 6 analyzes the macroeconomic and financial stability implications of policies. Section 7 concludes.

\section{Literature Review and our Contribution}

This paper constitutes a two-country version of the seminal paper of Iacoviello (2005), which introduces a financial accelerator that works through the housing sector, in the flavor of Aspachs and Rabanal (2010). However, it introduces cross-country housing-market heterogeneity as in Rubio (2014) or Rubio and 
Comunale (2017). This paper is also related to the recent literature on macroprudential and monetary policies in Iacoviello-type models such in the aforementioned Kannan, Rabanal and Scott (2012) or Rubio and Carrasco-Gallego $(2013,2014)$. However, it explores the issue in a two-country setting as in Brzoza-Brzezina et al. (2015).

Our paper contributes to this literature by looking at a two-country DSGE, modelled for Lithuania and the euro area, in which we analyze whether the monetary policy rule should respond to financial instability as well, or there should be instead a separate rule to deal with the latter one. To answer our research question, we provide a regular Taylor rule, as the pre-crisis policy setting, an extended Taylor rule in which the central bank takes care of both macroeconomic stability and financial stability (defined as the standard deviation of credit), and a case in which we have both a regular Taylor rule and a rule for macroprudential actions, based on LTV ratios reacting to borrowing. We believe this issue is crucial, especially in the context of the euro area and its member states, here represented by Lithuania as a small open economy with specific characteristics of the housing market, which makes it a very interesting case study. Having a centralized monetary policy, makes the macroprudential policy a way to act independently as a partial substitute for the lack of national monetary policies. ${ }^{7}$ However, our study makes the two policies working in a context of a monetary union with transmissions and relative obligations, looking at both the whole euro area and Lithuanian perspectives.

Our paper also relates to the literature on the interaction between monetary policy and macroprudential policy. This has been recently covered by Carrillo et al. (2016), in the context of a so-called "Tinbergen principle," by looking at whether the monetary policy rule should be expanded to introduce financial stability considerations, or there should be instead a separate financial policy rule. Indeed, their main point is if having two policy targets (price and financial stability) would indeed require two instruments or we can actually apply a one-rule regime with a monetary policy rule, based on both inflation and financial conditions (expected credit spreads, in their case). ${ }^{8}$ The authors' findings favor separate but well-coordinated monetary and financial policies. Moreover, the dual regime is significantly superior in terms of welfare gains.

Several other papers address the issue of whether central banks should react to financial stability conditions, or a separate financial authority at the national level is preferred. And the conclusions in the literature are rather different. They go from simply concluding that monetary policy authorities should

\footnotetext{
${ }^{7}$ See also Quint and Rabanal (2014).

${ }^{8}$ The "Tinbergen principle" argues that there should be two different instruments when there are two different policy goals.
} 
react to financial stability issues when macroprudential policies fail as an instrument of last resort ${ }^{9}$, while still keeping the authorities separated (Smets, 2014) $)^{10}$, to proposing a modified Taylor rule to include, for instance, a natural rate of interest (Taylor and Wieland, 2016) ${ }^{11}$, or an explicit financial variable (as house prices in Rubio and Carrasco-Gallego, 2015). Svensson (2015) and Yellen (2014) instead, are in favor of having a fully separated different authorities for the two objectives: one to address financial and macroprudential issues and a central bank focusing on price stability. Especially, Svensson (2015), points out that macroprudential policy cannot achieve price stability and monetary policy, from its side, is not able to guarantee financial stability, not ensuring that there are sufficient capital and liquidity buffers in the financial system. The author also stresses that the two policies indeed interact and only indirectly, for instance, monetary policy may influence financial stability via effects on lending and credit; or macroprudential policy can have an impact on inflation. Rubio and Carrasco-Gallego (2015) also consider this topic however, they do it in a closed economy setting. They conclude that welfare gains are maximized when the central bank aims at stabilizing inflation, responding only to prices and output, and the macroprudential regulator cares about financial stability. Lastly, Quint and Rabanal (2014), also study the optimal mix of monetary and macroprudential policies in an estimated two-country model of the euro area, ${ }^{12}$ representing core and periphery. ${ }^{13}$ They conclude that extending a monetary policy rule to react to credit aggregates improves welfare with respect to the original one, with borrowers being worse off under some conditions. Introducing a macroprudential instrument, further increases welfare but still with a trade-off between borrowers and savers.

\section{$3 \quad$ Model Setup}

We consider an infinite-horizon, two-country economy inside a monetary union. The home country is denoted by LIT and the rest of the union by EUR. Households consume, work, and demand real estate. There is a financial intermediary in each country that provides mortgages and accepts deposits from

\footnotetext{
${ }^{9}$ Smets (2014) suggests to allow the central bank to "lean against the wind" in case of financial stability troubles only if necessary, while maintaining its primary focus on price stability in the medium term.

${ }^{10}$ Smets (2014) also stresses the possible risks of having macroprudential actions delivered by a central bank. First, there is a risk that the reputation of the central bank is damaged, which may affect its overall independence and credibility. Second, it may give rise to time inconsistency problems and may lead to so-called "financial dominance."

${ }^{11}$ As recently stressed by Pedersen (2015), having a low natural real rate may drive an increase in risk taking and thus in the likelihood of asset price bubbles. This can have implications for financial stability.

${ }^{12}$ This paper seems to be the closest to our approach, by also applying the framework by Rubio (2013), and adding borrowing constraint á la Iacoviello (2005) with no default. The authors however estimate and not calibrate the model.

${ }^{13}$ In Quint and Rabanal (2014), the two regions of the euro area, i.e.core and periphery, are obtained by aggregating data for France and Germany for the first group and Greece, Ireland, Italy, Portugal, and Spain for the periphery.
} 
consumers. ${ }^{14}$ Each country produces one differentiated intermediate good, but households consume goods from both countries. For simplicity, housing is a non-traded good. We assume that labor is immobile across the countries. ${ }^{15}$ Firms follow a standard Calvo problem (after Calvo, 1983). In this economy, both final and intermediate goods are produced. Prices are sticky in the intermediate-goods sector. Monetary policy is conducted by a single central bank that responds to a weighted average of inflation in both countries. Analogous to the setting of the interest rate, there is a rule for the setting of the LTV, which serves as a macroprudential measure. We allow for housing-market heterogeneity across the countries.

\subsection{The Consumer's Problem}

There are three types of consumers in each country: unconstrained consumers, constrained consumers who borrow at a variable rate, and constrained consumers who borrow at a fixed rate. The proportion of each type of borrower is fixed and exogenous. ${ }^{16}$ Consumers can be constrained or unconstrained in the sense that constrained individuals need to collateralize their debt repayments in order to borrow from the financial intermediary. Interest payments in the next period cannot exceed a proportion of the future value of the current house stock. In this way, the financial intermediary ensures that borrowers are going to be able to fulfill their debt obligations in the next period. As in Iacoviello (2005), We assume that constrained consumers are more impatient than unconstrained ones. ${ }^{17}$ There is a financial intermediary in each country. The financial intermediary in each country accepts deposits from domestic savers, and it extends both fixed- and variable-rate loans to domestic borrowers.

\footnotetext{
${ }^{14} \mathrm{We}$ are aware that there are two possible presentations of banks in a DSGE model: financial intermediary approach and money creator approach. However, in order to make the model comparable with the standard literature, we prefer to stick to the more commonly used approach. In this way, our results can be related to other papers that introduce macroprudential rules in a DSGE framework such as Kannan et al. (2012) or Angelini et al. (2014). Our decision is thus practical, rather than theoretical or technical.

${ }^{15}$ This is a standard simplifying assumption, since the focus of the paper is on financial markets. We aknowledge the fact that labor mobility has been a factor within the euro area, however is not covered here. This is especially true for Lithuania. This resulted in labor shortage in the country and a significant emigration.

${ }^{16}$ According to the European Mortgage Federation, the type of mortgage contracts across countries responds to a large extent to institutional or cultural factors, which are out of the scope of the present model. In the short run, the proportion of each type of mortgage contract can fluctuate, but, typically, it does not imply a change in the fixed- or variable-rate category of the country.

${ }^{17}$ This assumption ensures that the borrowing constraint is binding in the steady state and that the economy is endogenously split into borrowers and savers.
} 


\subsubsection{Unconstrained Consumers (Savers)}

Unconstrained consumers in LIT maximize as follows:

$$
\max E_{0} \sum_{t=0}^{\infty} \beta^{t}\left(\ln C_{t}^{u}+j \ln H_{t}^{u}-\frac{\left(L_{t}^{u}\right)^{\eta}}{\eta}\right),
$$

Here, $E_{0}$ is the expectation operator, $\beta \in(0,1)$ is the discount factor for savers, and $C_{t}^{u}, H_{t}^{u}$, and $L_{t}^{u}$ are consumption at $t$, the stock of housing, and hours worked, respectively. $j$ represents the weight of housing in the utility function. $1 /(\eta-1)$ is the aggregate labor-supply elasticity.

Consumption is a bundle of domestically and foreign-produced goods, defined as: $C_{t}^{u}=\left(C_{L I T t}^{u}\right)^{n}\left(C_{E U R t}^{u}\right)^{1-n}$, where $n$ is the size of LIT.

The budget constraint for LIT is as follows:

$$
\begin{gathered}
P_{L I T t} C_{L I T t}^{u}+P_{E U R t} C_{E U R t}^{u}+Q_{L I T t} H_{t}^{u}+R_{L I T t-1} B_{t-1}^{u}+R_{t-1} D_{t-1}+\frac{\psi}{2} D_{t}^{2} \leq Q_{t} H_{t-1}^{u}+ \\
W_{t}^{u} L_{t}^{u}+B_{t}^{u}+D_{t}+P_{L I T t} F_{t}+P_{L I T t} S_{t}
\end{gathered}
$$

where $P_{L I T t}$ and $P_{E U R t}$ are the prices of the goods produced in Countries LIT and EUR, respectively, $Q_{t}$ is the housing price in LIT, $H_{t}^{u}$ is the stock of housing and $W_{t}^{u}$ is the wage for unconstrained consumers. $B_{t}^{u}$ represents domestic bonds denominated in the common currency. $R_{L I T t}$ is the nominal interest rate in LIT. Positive bond holdings signify borrowing, and negative signify savings. However, as we will see, this group will choose not to borrow at all: they are the savers in this economy. $D_{t}$ are foreignbond holdings by savers in LIT, who have indeed access to the international financial market. $R_{t}$ is the nominal rate of foreign bonds, which are denominated in euros. As is common in the literature, to ensure stationarity of net foreign assets we introduced a small quadratic cost of deviating from zero foreign borrowing, $\frac{\psi}{2} D_{t}^{2}$. Savers obtain interest on their savings. $S_{t}$ and $F_{t}$ are lump-sum profits received from the firms and the financial intermediary in LIT, respectively.

Dividing by $P_{L I T t}$, we can rewrite the budget constraint in terms of goods LIT $^{18}$ :

\footnotetext{
${ }^{18}$ The variables in small letters are taken divided by $P_{\text {LITt }}$.
} 
$C_{L I T t}^{u}+\frac{P_{E U R t}}{P_{L I T t}} C_{E U R t}^{u}+q_{L I T t} H_{t}^{u}+\frac{R_{L I T t-1} b_{t-1}^{u}}{\pi_{L I T t}}+\frac{R_{t-1} d_{t-1}}{\pi_{L I T t}}+\frac{\psi}{2} d_{t}^{2} \leq q_{L I T t} H_{t-1}^{u}+w_{t}^{u} L_{t}^{u}+b_{t}^{u}+d_{t}+F_{t}+S_{t}$,

where $\pi_{L I T t}$ denotes inflation for the goods produced in LIT, defined as $P_{L I T t} / P_{L I T t-1}$.

Maximizing (1) subject to (3), we obtain the first-order conditions for the unconstrained group:

$$
\begin{gathered}
\frac{C_{L I T t}^{u}}{C_{E U R t}^{u}}=\frac{n P_{E U R t}}{(1-n) P_{L I T t}} \\
\frac{1}{C_{L I T t}^{u}}=\beta E_{t}\left(\frac{R_{L I T t}}{\pi_{L I T t+1} C_{L I T t+1}^{u}}\right), \\
\frac{1-\psi d_{t}}{C_{L I T t}^{u}}=\beta E_{t}\left(\frac{R_{t}}{\pi_{L I T t+1} C_{L I T t+1}^{u}}\right), \\
w_{t}^{u}=\left(L_{t}^{u}\right)^{\eta-1} \frac{C_{L I T t}^{u}}{n}, \\
\frac{j}{H_{t}^{u}}=\frac{n}{C_{L I T t}^{u}} q_{L I T t}-\beta E_{t} \frac{n}{C_{L I T t+1}^{u}} q_{L I T t+1} .
\end{gathered}
$$

Equation (4) equates the marginal rate of substitution between goods to the relative price. Equation (5) is the Euler equation for consumption. Equation (6) is the first-order condition for net foreign assets. Equation (7) is the labor-supply condition. These equations are standard. Equation (8) is the Euler equation for housing and states that at the margin the benefits from consuming housing have to be equal to the costs.

Combining (5) and (6) we obtain a non-arbitrage condition between home and foreign bonds: ${ }^{19}$

$$
R_{L I T t}=\frac{R_{t}}{\left(1-\psi d_{t}\right)}
$$

Since all consumption goods are traded and there are no barriers to trade, we assume in this paper that the law of one price holds:

\footnotetext{
${ }^{19}$ The log-linearized version of this equation could be interpreted as the uncovered interest-rate parity.
} 


$$
P_{\text {LITt }}=P_{\text {LITt }}^{*}
$$

where variables with a star denote foreign variables and $P_{L I T t}^{*}$ is the foreign price of goods produced at home.

\subsubsection{Constrained Consumers (Borrowers)}

Constrained consumers in LIT are of two types: those who borrow at a variable rate and those who do so at a fixed rate. The difference between them is the interest rate they are charged. The variablerate constrained consumer faces $R_{L I T t}$, which will coincide with the rate set by the central bank. The fixed-rate borrower pays $\bar{R}_{L I T t}$, derived from the financial intermediary's problem. The proportion of variable-rate consumers in LIT is constant and exogenous and is equal to $\alpha_{L I T} \in[0,1]$.

Constrained consumers are more impatient than unconstrained ones, that is $\widetilde{\beta}<\beta$ in terms of discount factors for borrowers and savers respectively. Constrained consumers face a collateral constraint: the expected debt repayment in the next period cannot exceed a proportion of the expectation of tomorrow's value of today's stock of housing:

$$
\begin{aligned}
& E_{t} \frac{R_{\text {LITt }}}{\pi_{L I T t+1}} b_{t}^{c v} \leq k_{\text {LITt }} E_{t} q_{L I T t+1} H_{t}^{c v}, \\
& E_{t} \frac{\bar{R}_{\text {LITt }}}{\pi_{\text {LITt }+1}} b_{t}^{c f} \leq k_{\text {LITt }} E_{t} q_{L I T t+1} H_{t}^{c f},
\end{aligned}
$$

where equations (11) and (12) represent the collateral constraint for the variable- and fixed-rate borrower, respectively. $k_{L I T t}$ can be interpreted as the loan-to-value ratio in LIT. Notice that such models with collateral constraints, the LTV is typically considered exogenous. At the macroeconomic level, LTVs partly depend on exogenous factors such as regulation. This parameter is usually calibrated to match the average (market) LTV in the country analyzed. ${ }^{20}$ However, in this model, it can vary depending on economic conditions, as a macroprudential policy variable. ${ }^{21}$ For the setting of the fixed interest rate, $\bar{R}_{L I T t}$, we follow Rubio (2011). We assume that there is a financial intermediary in each country

\footnotetext{
${ }^{20}$ Due to data availability, we use the average new loans' LTV at origination.

${ }^{21}$ It has to be taking into account that in reality, macroprudential LTV caps are not always binding. Even a stable LTV cap inherently has a countercyclical effect as it is less binding after a crisis but is likely to become more binding as credit and housing prices pick up during the financial cycle (Matkènaitè et al., 2016).
} 
that accepts deposits from savers and extends both fixed and variable-rate mortgages to borrowers. For the two types of mortgage to be offered, the fixed-interest rate has to be such that the intermediary is indifferent between lending at a variable or fixed rate. $\bar{R}_{L I T t}$ will be an aggregate interest rate that contains information on all the past fixed-interest rates associated with past debt. Each period, this aggregate interest rate is updated with a new fixed interest rate that is an average discount average of all future variable interest rates.

Without loss of generality, we present the problem for the variable-rate borrower since for the fixed rate it is symmetrical. Variable-rate borrowers maximize their lifetime utility function:

$$
\max E_{0} \sum_{t=0}^{\infty} \widetilde{\beta}^{t}\left(\ln C_{t}^{c v}+j \ln H_{t}^{c v}-\frac{\left(L_{t}^{c v}\right)^{\eta}}{\eta}\right),
$$

where $C_{t}^{c v}=\left(C_{L I T t}^{c v}\right)^{n}\left(C_{E U R t}^{c v}\right)^{1-n}$, subject to the budget constraint (in terms of good LIT):

$$
C_{L I T t}^{c v}+\frac{P_{E U R t}}{P_{L I T t}} C_{E U R t}^{c v}+q_{L I T t} H_{t}^{c v}+\frac{R_{L I T t-1} b_{t-1}^{c v}}{\pi_{L I T t}} \leq q_{L I T t} H_{t-1}^{c v}+w_{t}^{c v} L_{t}^{c v}+b_{t}^{c v},
$$

and subject to the collateral constraint (11). Notice that variable-rate borrowers repay all debt every period and acquire new debt at the current new interest rate. This assumption implies that the interest rate on variable-rate mortgages is revised every period for the whole stock of debt and changed according to the policy rate. ${ }^{22}$ To make the problem for fixed-rate borrowers symmetrical and analogous to existing models with borrowing constraints, we assume the same debt-repayment structure for this type of borrower. Obviously, fixed-rate contracts are not revised every period. However, to make the model more realistic, but still tractable, the fixed-interest rate will be such that a revised fixed rate will be applied only on new debt, keeping constant the interest rate applied to existing debt. In this way, we reconcile the structure of the model with the fact that fixed-rate contracts are long term.

The first-order conditions for these consumers are as follows:

$$
\begin{gathered}
\frac{C_{L I T t}^{c v}}{C_{E U R t}^{c v}}=\frac{n P_{E U R t}}{(1-n) P_{L I T t}} \\
\frac{n}{C_{L I T t}^{c v}}=\widetilde{\beta} E_{t}\left(\frac{n R_{L I T t}}{\pi_{L I T t+1} C_{L I T t+1}^{c v}}\right)+\lambda_{t}^{c v} R_{L I T t},
\end{gathered}
$$

\footnotetext{
${ }^{22}$ This assumption is consistent with reality, in which variable-interest rates are revised very frequently and changed according to an interest-rate index tied to the interest rate set by the central bank.
} 


$$
\begin{gathered}
w_{t}^{c v}=\left(L_{t}^{c v}\right)^{\eta-1} \frac{C_{L I T t}^{c v}}{n}, \\
\frac{j}{H_{t}^{c v}}=\frac{n}{C_{L I T t}^{c v}} q_{L I T t}-\widetilde{\beta} E_{t} \frac{n}{C_{L I T t+1}^{c v}} q_{L I T t+1}-\lambda_{t}^{c v} k_{L I T t} E_{t} q_{L I T t+1} \pi_{L I T t+1} .
\end{gathered}
$$

These first-order conditions differ from those of unconstrained individuals. In the case of constrained consumers, the Lagrange multiplier on the borrowing constraint $\left(\lambda_{t}^{c v}\right)$ appears in equations (16) and (18). As in Iacoviello (2005), the borrowing constraint is always binding, so that constrained individuals borrow the maximum amount they are allowed, and their saving is zero. The problem for consumers is analogous in country EUR.

\subsection{Firms}

\subsubsection{Final-Goods Producers}

In LIT, there is a continuum of final-goods producers that aggregate intermediate goods according to the production function:

$$
Y_{L I T t}^{k}=\left[\int_{0}^{1} Y_{L I T t}^{k}(z)^{\frac{\varepsilon-1}{\varepsilon}} d z\right]^{\frac{\varepsilon}{\varepsilon-1}}
$$

where $\varepsilon>1$ is the elasticity of substitution among intermediate goods.

The total demand of intermediate-good $z$ is given by $Y_{L I T t}(z)=\left(\frac{P_{L I T t}(z)}{P_{L I T t}}\right)^{-\varepsilon} Y_{L I T t}$, and the price index is $P_{\text {LITt }}=\left[\int_{0}^{1} P_{L I T t}(z)^{1-\varepsilon} d z\right]^{\frac{1}{\varepsilon-1}}$.

\subsubsection{Intermediate-Goods Producers}

The intermediate-goods market is monopolistically competitive. Following Iacoviello (2005), intermediate goods are produced according to the following production function:

$$
Y_{L I T t}(z)=\xi_{t}\left(L_{t}^{u}(z)\right)^{\gamma_{L I T}}\left(L_{t}^{c}(z)\right)^{\left(1-\gamma_{L I T}\right)}
$$

where $\xi_{t}$ represents technology. We assume that $\log \xi_{t}=\rho_{\xi} \log \xi_{t-1}+u_{\xi t}$, where $\rho_{\xi}$ is the autoregressive coefficient and $u_{\xi t}$ is a normally distributed shock to technology. $\gamma_{L I T} \in[0,1]$ measures the relative size 
of each group in terms of labor ${ }^{23} . L_{t}^{c}$ is labor supplied by constrained consumers, defined as $\alpha_{L I T} L_{t}^{c v}+$ $\left(1-\alpha_{L I T}\right) L_{t}^{c f}$.

The first-order conditions for labor demand are the following: ${ }^{24}$

$$
\begin{gathered}
w_{t}^{u}=\frac{1}{X_{t}} \gamma_{L I T} \frac{Y_{L I T t}}{L_{t}^{u}}, \\
w_{t}^{c v}=w_{t}^{c f}=\frac{1}{X_{t}}\left(1-\gamma_{L I T}\right) \frac{Y_{L I T t}}{L_{t}^{c}},
\end{gathered}
$$

where $X_{t}$ is the markup, or the inverse of marginal cost.

The price-setting problem for the intermediate-goods producers is a standard Calvo-Yun case. An intermediate-goods producer sells goods at price $P_{L I T t}(z)$, and $1-\theta$ is the probability of being able to change the sale price in every period. The optimal reset price $P_{L I T t}^{O P T}(z)$ solves the following:

$$
\sum_{k=0}^{\infty}(\theta \beta)^{k} E_{t}\left\{\Lambda_{t, k}\left[\frac{P_{L I T t}^{O P T}(z)}{P_{L I T t+k}}-\frac{\varepsilon /(\varepsilon-1)}{X_{t+k}}\right] Y_{L I T t+k}^{O P T}(z)\right\}=0
$$

The aggregate price level is given as follows:

$$
P_{L I T t}=\left[\theta P_{L I T t-1}^{1-\varepsilon}+(1-\theta)\left(P_{L I T t}^{O P T}\right)^{1-\varepsilon}\right]^{1 /(1-\varepsilon)}
$$

Using (23) and (24) and log-linearizing, we can obtain the standard forward-looking Phillips curve ${ }^{25}$.

The firm problem is similar in EUR.

\subsection{Aggregate Variables and Market Clearing}

Given $\alpha_{L I T}$, the fraction of variable-rate borrowers in LIT, we can define aggregates across constrained consumers as the sum of variable-rate and fixed-rate aggregates, so that $C_{t}^{c} \equiv \alpha_{L I T} C_{t}^{c v}+\left(1-\alpha_{L I T}\right) C_{t}^{c f}$, $H_{t}^{c} \equiv \alpha_{L I T} H_{t}^{c v}+\left(1-\alpha_{L I T}\right) H_{t}^{c f}$ and $b_{t}^{c} \equiv \alpha_{L I T} b_{t}^{c v}+\left(1-\alpha_{L I T}\right) b_{t}^{c f}$.

Therefore, economy-wide aggregates in LIT are $C_{t} \equiv C_{t}^{u}+C_{t}^{c}, L_{t} \equiv L_{t}^{u}+L_{t}^{c}$. The aggregate supply of housing is fixed, so that market clearing requires $H_{t} \equiv H_{t}^{u}+H_{t}^{c}=H{ }^{26}$

\footnotetext{
${ }^{23}$ It can be seen as labor-income share and proxy for the differences in debt to GDP.

${ }^{24}$ Symmetry across firms allows avoiding index $z$.

${ }^{25}$ The Phillips curve is as the following: $\hat{\pi}_{L I T t}=\beta \hat{\pi}_{L I T t+1}-\widetilde{k} \hat{x}_{t}+u_{L I T t}$, where $\hat{x}$ is $1 /$ real marginal cost and $\widetilde{k}=$ $[(1-\theta)(1-\beta \theta) / \theta]$.

${ }^{26}$ An endogenous supply of housing could be easily introduced in a two-sector version of this model. However, the qualitative results would not change for the demand side of the model which is the focus of this paper. For two-sector models, see, for example, Iacoviello and Smets (2006) or Iacoviello and Neri (2010).
} 
The market clearing condition for the final good in LIT is $n Y_{L I T t}=n C_{L I T t}+(1-n) C_{L I T t}^{*}+$ $n \frac{\psi}{2} d_{t}^{2}$. Domestic financial markets clear: $b_{t}^{c}=b_{t}^{u}$. The world bond market clearing condition is $n d_{t}+$ $(1-n) \frac{P_{E U R t}}{P_{\text {LITt }}} d_{t}^{*}=0$, where $d_{t}$ denotes the foreign bonds in real terms. The net foreign asset position follows $d_{t}=\frac{R_{t-1}}{\left(1-\psi d_{t}\right) \pi_{L I T t}} d_{t-1}+Y_{L I T t}-C_{L I T t}-\frac{P_{E U R t}}{P_{L I T t}} C_{E U R t}$. Everything is similar in EUR.

\subsection{Monetary Policy}

\subsubsection{Taylor Rule}

The model closes with a Taylor rule, with interest-rate smoothing for interest-rate setting by a single central bank, ${ }^{27}$

$$
R_{t}=\left(R_{t-1}\right)^{\rho}\left(\left[\left(\pi_{L I T t}\right)^{n}\left(\pi_{E U R t}\right)^{(1-n)}\right]^{\left(1+\phi_{\pi}\right)} R\right)^{1-\rho} \varepsilon_{R, t}
$$

$0 \leq \rho \leq 1$ is the parameter associated with interest-rate inertia. $\left(1+\phi_{\pi}\right)$ measures the sensitivity of interest rates to current inflation. $\varepsilon_{R, t}$ is a white noise shock process with zero mean and variance $\sigma_{\varepsilon}^{2} . R$ is the interest rate in steady state. This rule is consistent with the primary objective of the ECB being price stability.

\subsubsection{Extended Taylor Rule}

As part of the discussion, we also consider an extended Taylor rule in which the central bank takes care of both macroeconomic and financial stability. It is extended in the sense that the interest rate setting also takes into account credit variables. The framework is analogous to the simple Taylor rule in the sense that the response of the interest rate to credit will take into account this variable in all the countries of the union, appropriately weighted by their country size.

$$
R_{t}=\left(R_{t-1}\right)^{\rho}\left(\left[\left(\pi_{L I T t}\right)^{n}\left(\pi_{E U R t}\right)^{(1-n)}\right]^{\left(1+\phi_{\pi}\right)}\left[\left(\frac{b_{L I T t}}{b_{L I T}}\right)^{n}\left(\frac{b_{E U R t}}{b_{E U R}}\right)^{(1-n)}\right]^{\phi_{b}} R\right)^{1-\rho} \varepsilon_{R, t},
$$

\footnotetext{
${ }^{27}$ This type of rule is also used in other monetary-union models. See Iacoviello and Smets (2006) or Aspachs and Rabanal (2008). Furthermore, as shown in Iacoviello (2005) and Rubio and Carrasco-Gallego (2013), a rule that only responds to inflation enhances the financial accelerator.
} 


\subsection{LTV Policy}

As an approximation for the way macroprudential policy works in the euro area, we consider a rule for the LTV. ${ }^{28}$ In standard models, the LTV is a fixed parameter which is not affected by economic conditions. However, we can think of regulations of LTVs as a way to moderate credit booms. When the LTV (cap) is high, the collateral constraint is less tight. And, since the constraint here is binding, borrowers will borrow as much as they are allowed to. Lowering the LTV tightens the constraint and therefore restricts the loans that borrowers can obtain. Recent research on macroprudential policies has proposed simple rules for the LTV so that it reacts inversely to variables such that the growth rates of GDP, credit, the credit-to-GDP ratio or house prices. ${ }^{29}$ We decided to make the rule more parsimonious allowing the LTV to react to borrowing. This will help for a further study on the interactions with monetary policy. Here, we assume that there exists a macroprudential Taylor-type rule for the LTV, so that it responds to deviations of credit from its steady state. ${ }^{30}$ We consider a decentralized macroprudential policy in which each country can implement its own rule:

$$
\begin{gathered}
k_{L I T t}=k_{S S L I T}\left(\frac{b_{L I T t}}{b_{L I T}}\right)^{-\phi_{b}^{L I T}}, \\
k_{E U R t}=k_{S S E U R}\left(\frac{b_{E U R t}}{b_{E U R}}\right)^{-\phi_{b}^{E U R}} .
\end{gathered}
$$

where $k_{S S L I T}, b_{L I T}$ are the steady-state values for the loan-to-value ratio and borrowing in LIT. $\phi_{b}^{L I T}, \phi_{b}^{E U R} \geq$ 0 measure the response of the loan-to-value to deviations of borrowing from its steady state in Lithuania and the rest of the euro area, respectively. This kind of rule would be countercyclical, delivering a lower LTV in credit booms, therefore restricting the credit in the economy.

\footnotetext{
${ }^{28}$ The literature has shown that restricting credit from the demand side (LTV) or the supply side (Capital requirements, CRR) show similar results on the macroeconomy (See for instance Angelini et al., 2014). Therefore, we expect the conclusions of the paper to hold. We prefer to use the LTV limit because it is not controled by Basel regulations as the CRR and countries have more freedom to set it.

${ }^{29}$ With a macroprudential orientation, Kannan et al., (2012) also examine a monetary policy rule that reacts to prices, output and changes in collateral values with a macroprudential instrument based on the LTV; Funke and Paetz (2012) consider a non-linear version of a macroprudential rule for the LTV.

${ }^{30}$ We have also experimented with rules that react to output and house prices and results for the dynamics of the model are similar. The first variable would correspond to the objective of the macroprudential regulator to moderate booms in the economy that could lead to an excessive credit growth. Drehmann et al. (2010) also point out that the deviations of credit from its long-term trend are very good indicators of the increase in systemic risk, which is the macroprudential attention. As for the house prices, given collateral constraints, they are the key causal variable for the dynamics of loans to households, and it appears to correspond to the actual behavior of policymakers (Angelini et al., 2012).
} 


\subsection{Welfare Measure}

In order to provide a measure for welfare, we numerically evaluate how cross-country asymmetries affect welfare for a given policy rule and for technology shocks. As discussed in Benigno and Woodford (2012), the two approaches that have recently been used for welfare analysis in DSGE models include either characterizing the optimal Ramsey policy, or solving the model using a second-order approximation to the structural equations for given policy and then evaluating welfare using this solution. As in Mendicino and Pescatori (2007), we take this latter approach to be able to evaluate the welfare of the three types of agents separately. ${ }^{31}$ The individual welfare for savers and borrowers in LIT is defined, respectively, as follows:

$$
\begin{aligned}
V_{u, t} & \equiv E_{t} \sum_{m=0}^{\infty} \beta^{m}\left(\ln C_{t+m}^{u}+j \ln H_{t+m}^{u}-\frac{\left(L_{t+m}^{u}\right)^{\eta}}{\eta}\right), \\
V_{c v, t} & \equiv E_{t} \sum_{m=0}^{\infty} \widetilde{\beta}^{m}\left(\ln C_{t+m}^{c v}+j \ln H_{t+m}^{c v}-\frac{\left(L_{t+m}^{c v}\right)^{\eta}}{\eta}\right),
\end{aligned}
$$

Following Mendicino and Pescatori (2007), we define social welfare in LIT as a weighted sum of the individual welfare for the different types of households:

$$
V_{t}=(1-\beta) V_{u, t}+(1-\widetilde{\beta})\left[\alpha_{A} V_{c v, t}+\left(1-\alpha_{A}\right) V_{c f, t}\right]
$$

Borrowers and savers' welfare are weighted by $(1-\widetilde{\beta})$ and $(1-\beta)$, respectively, so that the two groups receive the same level of utility from a constant consumption stream. Everything is symmetrical for EUR.

Total welfare is defined as a weighted sum of the welfare in the two countries:

$$
W_{t}=n V_{t}+(1-n) V_{t}^{*}
$$

In order to make the results more intuitive, we present welfare changes in terms of consumption equivalents. We use as a benchmark the welfare evaluated when the macroprudential policy is not active

\footnotetext{
${ }^{31}$ We used the software Dynare to obtain a solution for the equilibrium implied by a given policy by solving a second-order approximation to the constraints, then evaluating welfare under the policy using this approximate solution, as in SchmittGrohe and Uribe (2004). See Monacelli (2006) for an example of the Ramsey approach in a model with heterogeneous consumers.
} 
and compare it with the welfare obtained when such policy is implemented. ${ }^{32}$

\section{Parameter Values}

Parameters are calibrated to reflect the economy of Lithuania and the rest of the euro area. Some of the parameters are standard and are common for both economies and some others will be specifically calibrated for each country. Tables 1 and 2 present a summary of the parameter values.

Discount factors are set to be common in both economies, following the standard values in the literature. The discount factor for savers, $\beta$, is set to $0.99 .{ }^{33}$ The discount factor for borrowers, $\widetilde{\beta}$, is set to $0.98 .^{34}$ The steady-state weight of housing in the utility function, $j$, is set to 0.12 and 0.14 , in the euro area and Lithuania, respectively. This parameter pins down the ratio of housing wealth to GDP, since the latter in the steady state is a function of this parameter. ${ }^{35}$ We set $\eta=2$, implying a value of the labor supply elasticity of $1 .^{36}$ For the LTV we consider a steady-state value of 0.68 and 0.78 , for the euro area and Lithuania, respectively, taking the LTV observed in the data. ${ }^{37}$ The labor-income share of unconstrained consumers, $\gamma$, is set to $0.7 .^{38}$ We pick a value of 6 for $\varepsilon$, the elasticity of substitution among intermediate goods. This value implies a steady-state markup of 1.2. The probability of not changing prices, $\theta$, is set to 0.75 , implying that prices change every four quarters on average. For the Taylor rule parameters, we used $\rho=0.8, \phi_{\pi}=0.5$. The first value reflects a realistic degree of interest-rate smoothing. ${ }^{39} \phi_{\pi}$ is consistent with the original parameters proposed by Taylor in 1993. We consider $\alpha$, the proportion of variable-rate mortgages, to be 0.45 and 0.82 , in the euro area and Lithuania, respectively. The size of Lithuania is considered to be $0.35 \%{ }^{40}$ A technology shock was a 1 per cent positive technology with 0.9 persistence. ${ }^{41}$ For simulations, we set $\phi_{b}^{L I T}=\phi_{b}^{E U R}=\phi_{b}=0.05$.

\footnotetext{
${ }^{32}$ We follow Ascari and Ropele (2009).

${ }^{33}$ Since the seminal paper by Kydland and Prescott (1982), the literature on DSGE models considers a calibrated value of the discount factor of 0.99 as the standard value for this parameter.

${ }^{34}$ Lawrance (1991) estimated discount factors for poor consumers at between 0.95 and 0.98 at quarterly frequency.

${ }^{35}$ Following Iacoviello and Neri (2010), we use 1.2, value that reflects the ratio of housing wealth to GDP across most industrialized countries as a proxy for the euro area. This ratio is higher though in Lithuania.

${ }^{36}$ Microeconomic estimates usually suggest values in the range of 0 and 0.5 (for males). Domeij and Flodén (2006) showed that in the presence of borrowing constraints this estimate could have a downward bias of 50 per cent.

${ }^{37}$ Note that the macroprudential LTV cap in Lithuania since 2011 is 85 per cent, which is higher than the average LTV in the last decade.

${ }^{38}$ This value is in the range of the estimates of Iacoviello (2005) and Iacoviello and Neri (2010) for the US, and Campbell and Mankiw (1991) for the US, Canada, France, and Sweden. Therefore, we take it as valid for most of the countries of the euro area.

${ }^{39}$ See McCallum (2001).

${ }^{40}$ Even though Lithuania is such a small country, we still want to keep a two-country setting to be able to study the interaction between policies in Lithuania and the rest of the euro area and potentially centralized vs. decentralized policies.

${ }^{41}$ This high persistence value for technology shocks is consistent with what is commonly reported in the literature. Smets and Wouters (2002) estimated a value of 0.822 for this parameter in Europe; Iacoviello and Neri (2010) estimated it as 0.93
} 
We set this number arbitrarily to a low value to give a sense of how the macroprudential rule works. Tables 1 and 2 present a summary of the parameter values. ${ }^{42}$

Table 1: Country-specific parameter values

\begin{tabular}{|c|c|c|c|}
\hline & EUR & LIT & \\
\hline$j$ & 0.12 & 0.14 & Weight of housing in utility function \\
\hline$k$ & 0.68 & 0.78 & Average loan-to-value ratio \\
\hline$\alpha$ & 0.45 & 0.82 & Degree of variability of interest rate \\
\hline$n$ & 0.9965 & 0.0035 & Country size \\
\hline
\end{tabular}

\begin{tabular}{|c|c|c|}
\hline \multicolumn{3}{|c|}{ Table 2: Common parameter Values } \\
\hline \hline$\beta$ & .99 & Discount factor for savers \\
\hline$\widetilde{\beta}$ & .98 & Discount factor for borrowers \\
\hline$\eta$ & 2 & Parameter associated with labor elasticity \\
\hline$\gamma$ & .70 & Labor-Income share for savers \\
\hline$\varepsilon$ & 6 & Elasticity of substitution among intermediate goods \\
\hline$\rho$ & 0.8 & Interest-rate smoothing in Taylor rule \\
\hline$\phi_{\pi}$ & .5 & Inflation parameter in Taylor rule \\
\hline$\phi_{b}$ & .05 & Credit parameter in Taylor rule \\
\hline$\phi_{b}^{L I T}$ & .05 & Credit parameter in LTV rule, Lithuania \\
\hline$\phi_{b}^{E U R}$ & .05 & Credit parameter in LTV rule, euro area \\
\hline$\rho_{\xi}$ & 0.9 & Technology shock persistence \\
\hline
\end{tabular}

\section{Shock Transmission}

In this section, we study the dynamics of the model by showing impulse-responses to a monetary policy shock, a technology shock and a house price shock, when there are and there are not macroprudential policies, using the parameter values shown in Table 2. As in the previous section, we consider two types of macroprudential policies: an extended Taylor rule in which the central bank takes care of financial stability vs. a rule for the LTV, in which each authority has separate objectives (TR+LTV Rule).

for the US.

${ }^{42}$ For Lithuania, the average LTV, the percentage of variable/fixed rates, as well as housing wealth/GDP (used to calculate the weight of housing in the utility function) are based on data up to 2014 and averaged over the period 2005-2014. Hence, the calibrated parameters refer to the mortgage conditions in the country over the crisis/post-crisis period. 

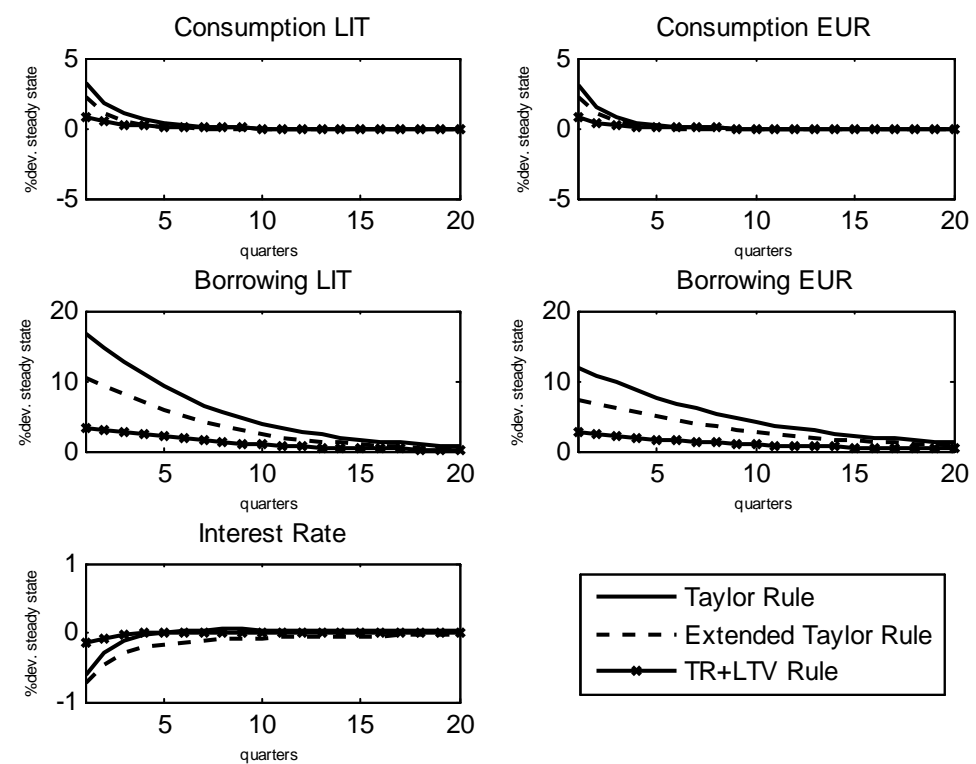

Figure 1: Impulse Responses to a Monetary Policy shock. Benchmark, Extended Taylor rule and LTV rule.
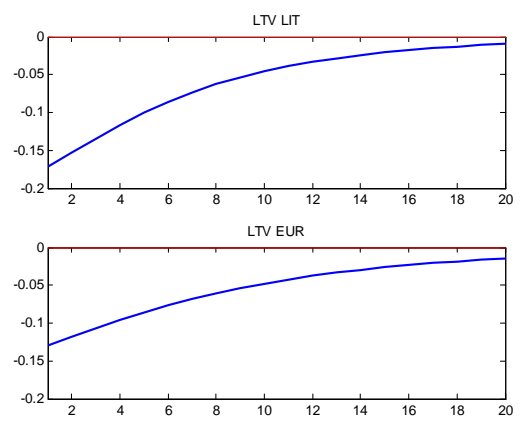

Figure 2: LTV Response to a Monetary Policy Shock. TR+LTV Rule.

\subsection{Impulse responses to a monetary policy shock}

Figure 1 presents impulse responses to a monetary policy shock. This represents a decrease in the interest rate by the ECB, in order to reflect an expansionary shock that increases risk in the economy and gives rise to macroprudential policies. As it is an expansionary common shock, borrowing in both Lithuania and the rest of the euro area increase. This is due to lower cost of borrowing. However, the increase in borrowing is stronger in Lithuania, given the nature of its mortgage rate. Variable rates in Lithuania make that the pass-through of the policy rate to the actual borrowing rate is stronger and thus the increase in borrowing is higher than for its partners. Given wealth effects and the increase in borrowing, consumption in both countries also goes up. The hike of credit gives rise to the activation of 
macroprudential policies. Both the extended Taylor rule and the LTV rule respond countercyclically to credit growth and therefore cut it, each one with its own instrument. Figure 2 shows how, for the case in which the LTV rule is active, the LTV decreases both in Lithuania and in the rest of the euro area. We see that for this shock, the LTV rule is the most effective one in order to reduce credit. A decrease of the LTV would partially offset the effects of the expansionary monetary policy shock. As a result, the impact of the shock on consumption would be mitigated, in a stronger way for the case of the LTV rule.

\subsection{Impulse Responses to a Technology Shock}

Figure 3 presents impulse responses to a technology shock in both countries. This is also by nature an expansionary shock and makes credit increase. Furthermore, as a reaction, the ECB policy rate goes down and this boosts credit even more. As in the previous case, variable rates in Lithuania make borrowing increase by more in this country than in the rest of the euro area. Thus, this shock also calls for macroprudential policies to be in place and soften the credit expansion (Figure 4 displays the decrease in the LTV in both countries). When macroprudential policies are activated, borrowing does not increase as much as in the benchmark case. We also see that, given that both macroprudential rules are countercyclical, the real economy gets also affected and the increase in consumption in both countries is also mitigated. However, we see that for the case of this shock, the extended Taylor rule reduces credit in a more substantial way than the LTV rule.

\subsection{Impulse Responses to a House Price Shock}

Figure 5 describes impulse responses to a house price shock both in Lithuania and in the rest of the euro area. ${ }^{43}$ We see from the figure that the house price shock has stronger effects in Lithuania and this causes credit to increase by more in this country. This creates strong effects on mortgaged houses and on consumption. In the rest of the euro area, the effects are similar but weaker, are more concentrated in the housing market, producing a slight decrease in consumption. Macroprudential policies act countercyclically and soften the increase in credit in both countries (See figure 6). In this case, the extended Taylor rule reduces credit by more in the rest on the euro area while the LTV rule is more effective in Lithuania.

\footnotetext{
${ }^{43}$ House prices are driven by housing demand. Therefore, housing demand shocks can also be interpreted as house price shocks.
} 

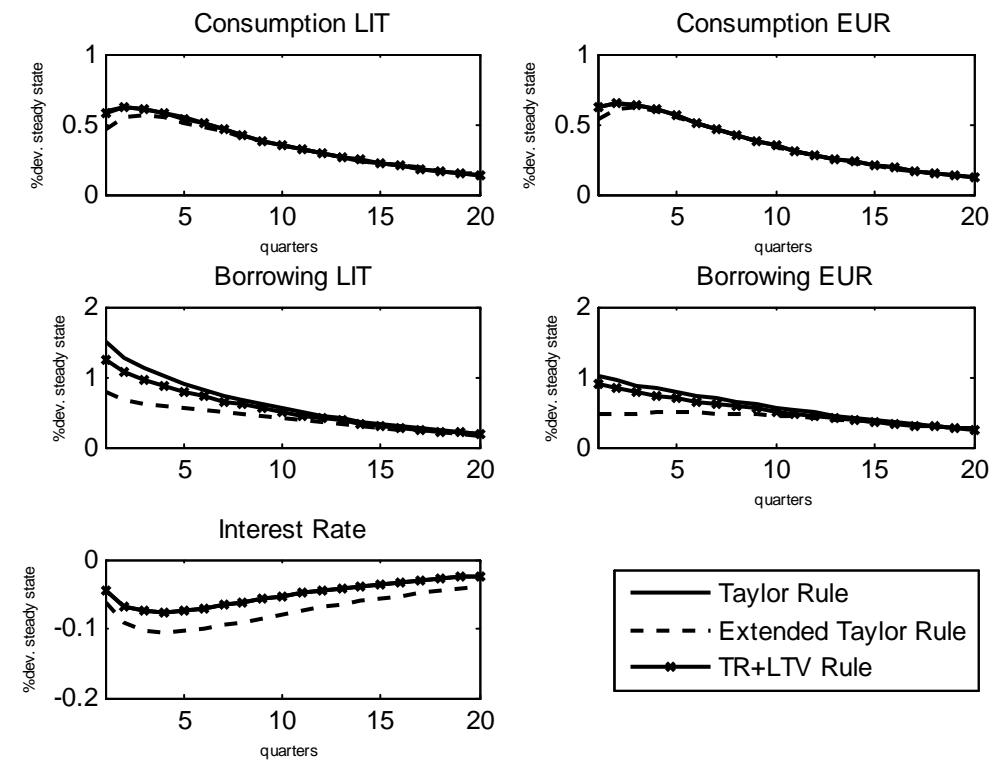

Figure 3: Impulse Responses to a Technology shock. Benchmark, Extended Taylor rule and LTV rule.
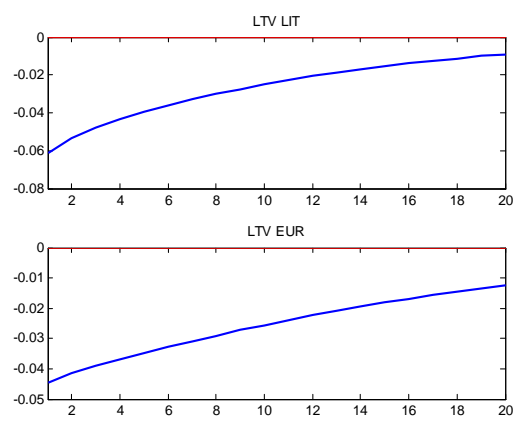

Figure 4: LTV Response to a Technology Shock. TR+LTV Rule.

\section{Financial and Macroeconomic Stability}

In this section, we study the implications of each setting (Taylor rule, extended Taylor rule and Taylor and LTV rule) for financial and macroeconomic stability. We approximate financial stability by the standard deviation of credit. Macroeconomic stability corresponds to the standard deviation of inflation and output. Here we try to assess the implication of having monetary policy with the interest rate in charge of financial stability as opposed to a different instrument, namely the LTV, taking care of this goal and leaving monetary policy with the single objective of price stability.

Svensson (2012) argues that conducting monetary policy and financial-stability policy in an integrated way may be inappropriate, since monetary policy and financial-stability policy are distinct and separate policies with different objectives and different instruments. Tinbergen (1952) put forth what we now 

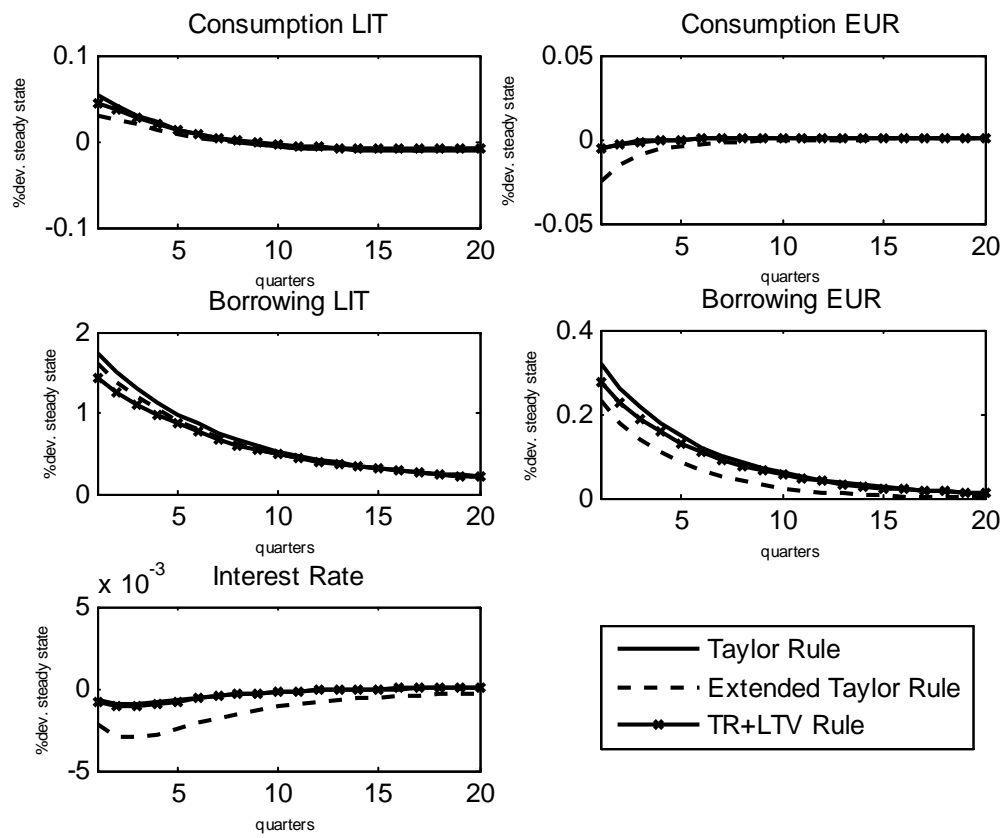

Figure 5: Impulse Responses to a House Price shock. Benchmark, Extended Taylor rule and LTV rule.
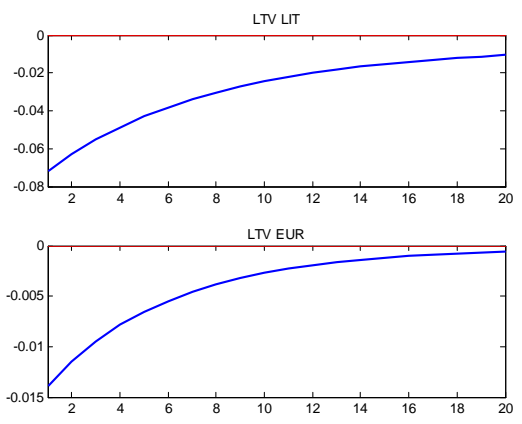

Figure 6: LTV Response to a House Price Shock. TR+LTV Rule.

call the 'Tinbergen principle,' that policymakers need at least one independent policy instrument for each policy objective. Since the policy interest rate is used by monetary policymakers to achieve the objective of price stability, at least one other instrument is required to achieve the additional objective of financial stability of macroprudential policy. Svensson (2012) suggests that monetary policy should be in charge of price stability while macroprudential policy needs to address financial stability. We try to shed some light to the debate with our results. ${ }^{44}$

\footnotetext{
${ }^{44}$ The macroprudential authority is assumed to be time-consistent and "hawkish", which does not have to be the case in practice (for example, the institutional set-up ensuring the independence of the authority could play a role). Subsequently, if the macroprudential policy rule were different, the results might not be so clear-cut.
} 
Table 3: Macroeconomic and Financial volatilities

\begin{tabular}{|l|l|l|l|l|l|l|}
\hline \hline & \multicolumn{3}{|l|}{ Lithuania } & \multicolumn{3}{l|}{ Euro } \\
\cline { 2 - 7 } & $\sigma_{\pi}$ & $\sigma_{y}$ & $\sigma_{b}$ & $\sigma_{\pi}$ & $\sigma_{y}$ & $\sigma_{b}$ \\
\cline { 2 - 8 } Taylor Rule & 0.2286 & 1.9984 & 3.2399 & 0.2253 & 1.9959 & 2.8351 \\
Extended Taylor Rule & 0.3811 & 1.9294 & 2.0391 & 0.3757 & 1.9117 & 1.9970 \\
TR+LTV Rule & 0.2299 & 1.9965 & 2.8115 & 0.2264 & 1.9944 & 2.5450 \\
\hline
\end{tabular}

Table 3 presents the macroeconomic and financial volatilities for each macroprudential policy setting. ${ }^{45}$ We can interpret the first row of the table as a benchmark in which monetary policy responds to inflation and there are no macroprudential policies in place. This would be the pre-crisis policy setting. The second row illustrates equation (26), in which the Taylor rule is extended to include credit variables and take care of financial stability in addition to price stability. Finally, the third row could correspond to a situation in which the central bank's objective is the union price stability while there are national macroprudential authorities that maintain financial stability.

We see that, initially, without macroprudential policies, the financial scenario in Lithuania is more unstable than in the rest of the euro area. Variable-rate mortgages, high LTVs and different housing characteristics make borrowing more volatile in this country. When macroprudential policies are introduced, we see that the volatility of credit decreases in all cases. Including credit variables in the Taylor rule is also very effective for financial stability purposes. However, it clearly comes at the cost of increasing macroeconomic instability, especially coming from inflation. Having the central bank taking care of both objectives at the same time creates conflicts in reaching both at the same time. When there is a separate macroprudential authority taking care of financial stability, the central bank can do its job and macroeconomic stability is not in danger. With respect to the benchmark case, the volatility of borrowing is reduced, although not as much as with an extended Taylor rule.

As a complement to Table 3, Table 4 presents welfare results:

\footnotetext{
${ }^{45}$ We use the Dynare toolkit to simulate our model. Using this package, we can calculate both theoretical moments and simulated moments. For linearized models, both approaches deliver very close results.
} 


\begin{tabular}{llcc}
\hline \hline Table 4: Welfare Gains & & \\
\hline \hline & & Lithuania & Euro \\
\hline \hline \multirow{2}{*}{ Extended Taylor Rule } & Savers & -0.010 & -0.099 \\
& Borrowers & 11.372 & 13.364 \\
& Total & 0.0065 & 0.0089 \\
\hline \hline \multirow{2}{*}{ SR+LTV Rule } & Savers & -0.0015 & -0.0015 \\
& Borrowers & 0.0435 & 0.0821 \\
& Total & 0.0211 & 0.0536 \\
\hline \hline
\end{tabular}

Consistently with Table 3, we can observe that having the two authorities taking care of different objectives is more beneficial for the whole economy, since welfare gains are larger in this case, in line with Carrillo et al. (2016). We also observe that borrowers prefer the extended Taylor rule because it is more effective in terms of achieving financial stability. However, this comes at the expense of higher welfare losses for savers because macroeconomic stability is compromised.

In order to convey our results and as a robustness check, we present the volatilities implied by both macroprudential policies for different values of the credit reaction parameter $\phi_{b}$ in both the extended Taylor rule and the LTV rule.

Figure 7 presents the volatility of credit implied by increasing the aggressiveness of macroprudential policies. We take the volatility of credit as an indicator of financial stability, in the sense that if it gets lower, it means that the financial system is more stable. We check how the volatility of credit changes when we increase the credit reaction parameter for both the extended Taylor rule and the LTV rule. We find that in Lithuania, the starting point with respect to the volatility of credit is higher than in the rest of the euro area, because of the above mentioned special characteristics of this economy with respect to its European partners, that make the financial system of this country more sensitive to shocks. The figure shows that both rules are effective in terms of reducing the volatility of borrowing and therefore in bringing a more stable financial system, the goal of macroprudential policies. However, the macroprudential Taylor rule seems to be more effective for this purpose in both countries, at least for the range of parameters that we are considering. Nevertheless, figure 7 only considers the financial stability, the objective of macroprudential policy, and does not consider macroeconomic stability.

Figures 8 and 9 display the macroeconomic and financial stability trade-offs implied by each macroprudential policy, in conjunction with monetary policy. Figure 8 shows the volatility of inflation, output 

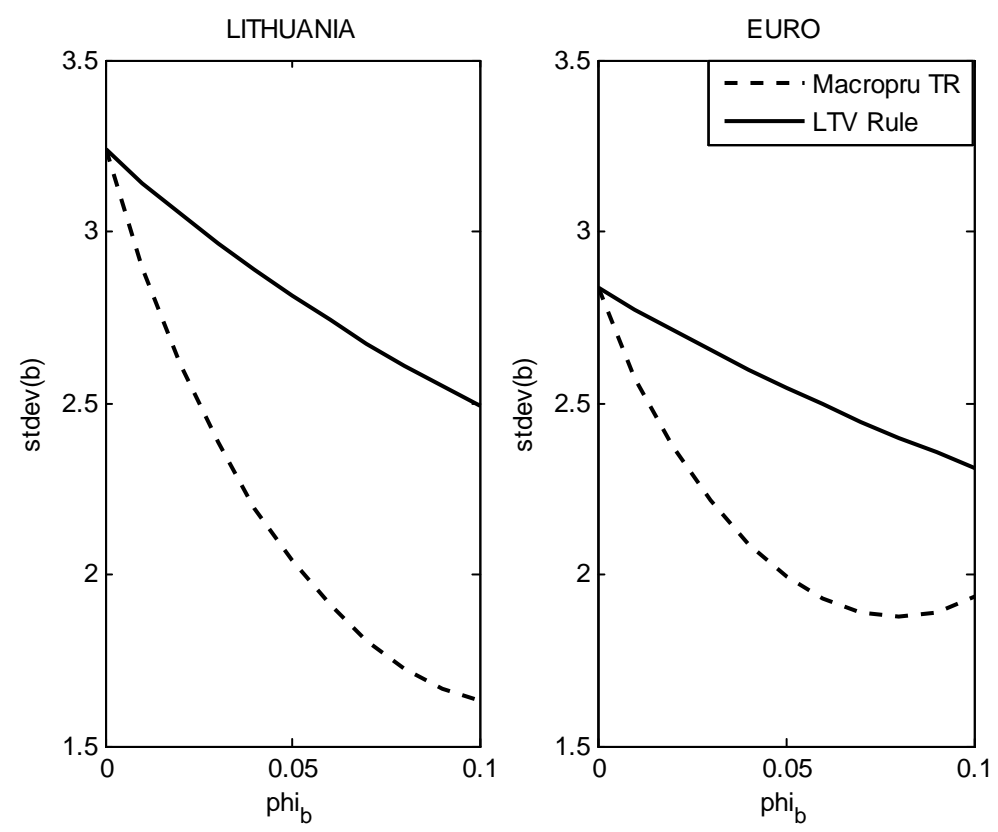

Figure 7: Financial stability implied by increasing the credit reaction parameter (Macroprudential TR vs. LTV rule)

and credit for the extended Taylor rule for monetary policy. We can actually see that even though this rule is very effective in reducing the volatility of credit, it comes with a cost in terms of inflation. The volatility of output slightly improves with the aggressiveness of the rule with respect to credit, but the inflation one worsens. Therefore, when using the interest rate as the only instrument both for monetary and macroprudential policy, there is a trade-off between stabilizing the financial system and keeping prices stable, which should be the primary goal of monetary policy. Monetary and macroprudential policy objectives enter in conflict if there is just one instrument for two goals.

On the contrary, figure 9 displays the volatilities implied by increasing the aggressiveness of the LTV rule. We can see that in this case, although not as effective as the previous case, this rule manages to achieve the goal of increasing financial stability without compromising the objectives of monetary policy. This reinforces the "Tinbergen principle" which argues that there should be two different instruments when there are two different policy goals. ${ }^{46}$

\section{Concluding Remarks}

In this paper we develop a two-country DSGE model with housing to study the implications of macroprudential policies in both Lithuania and the rest of the euro area, given the recent entrance of Lithuania

\footnotetext{
${ }^{46}$ This result is in line with Quint and Rabanal (2014), which studied core and periphery countries in the euro area.
} 

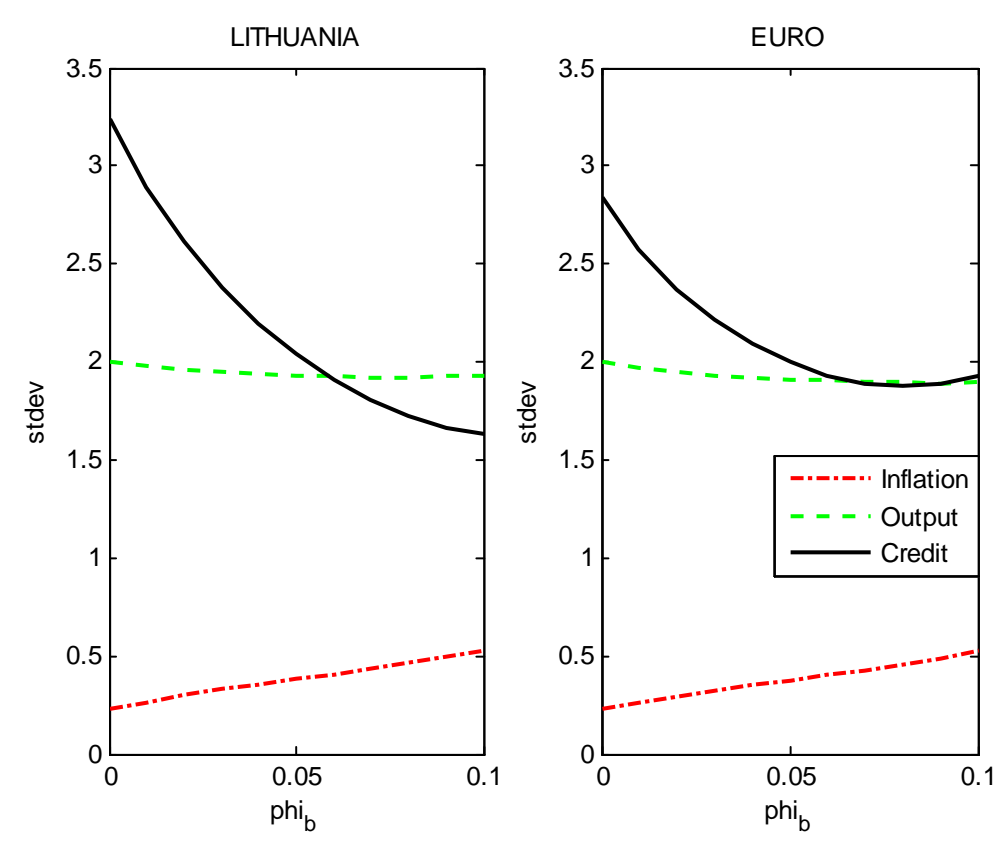

Figure 8: Volatilities implied by increasing the credit reaction parameter in the Macroprudential Taylor rule.

in the euro area. One of the countries is calibrated to reflect the Lithuanian economy, while the other one represents the rest of the euro area. We consider two different ways of implementing macroprudential policies. In the first one, the ECB extends its goals to also include financial stability. In this case, with just one instrument, namely the interest rate, the central bank takes care of two objectives: price and financial stability. In the second policy scenario, the central bank focuses on price stability having the interest rate as an instrument while a separate macroprudential authority uses an LTV rule to pursue financial stability. First, we illustrate the dynamics of the model for both rules by showing impulse responses to a monetary policy shock, a technology shock and a house price shock. Results show that in Lithuania, shocks are transmitted in a stronger way given variable rates in this country, higher mortgage debt and LTVs. However, macroprudential policies are indeed successful at mitigating the effects on shocks on credit growth. Then, we study the implications of both policy scenarios for macroeconomic and financial stability. We find that both rules are effective in terms of reducing the volatility of borrowing and therefore in bringing a more stable financial system, the goal of macroprudential policies. However, the macroprudential Taylor rule seems to be more effective for this purpose in both countries. Nevertheless, even though this rule is very effective in reducing the volatility of credit, it comes with a cost in terms of inflation volatility. When using the interest rate as the only instrument both for monetary and macroprudential policy, there is a trade-off between stabilizing the financial system and 

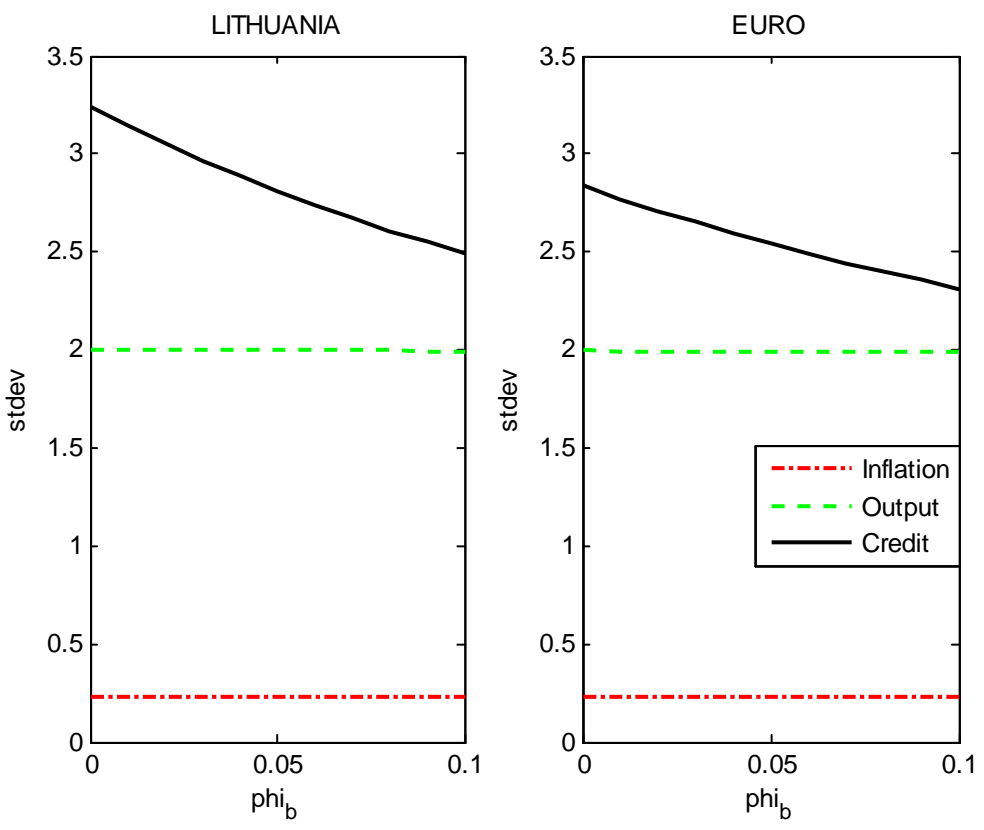

Figure 9: Volatilities implied by increasing the credit reaction parameter in the LTV rule.

keeping prices stable, which should be the primary goal of monetary policy. The LTV rule, although not as effective as the extended Taylor rule, manages to achieve the goal of increasing financial stability without compromising the objectives of monetary policy, which it is still the goal of a standard Taylor Rule. Welfare results are consistent with these findings. 


\section{References}

[1] Andrés, J., Arce, O., (2008), "Banking Competition, Housing Prices and Macroeconomic Stability ", Bank of Spain Working Paper, 0830

[2] Andres, J., Arce, O., Thomas, C., (2013), "Banking Competition, Collateral Constraints, and Optimal Monetary Policy ", Journal of Money, Credit and Banking, Supplement to Vol 45, No 2

[3] Angelini, P., Neri, S., Panetta, F., (2014), "The Interaction between Capital Requirements and Monetary Policy." Journal of Money, Credit and Banking, Volume 46, Issue 6, pp. 1073-1112

[4] Ascari, G., Ropele, T., (2009), "Disinflation in a DSGE Perspective: Sacrifice Ratio or Welfare Gain Ratio?", Kiel Institute for the World Economy Working Paper, 1499

[5] Aspachs, O., Rabanal, P., (2010), "The Drivers of Housing Prices in Spain", SERIEs, 1 (1), 101-130

[6] Bank of Lithuania, (2013, 2014, 2015), Financial Stability Review

[7] Benigno, P., Woodford, M., (2012), "Linear-Quadratic Approximation of Optimal Policy Problems", Journal of Economic Theory, Elsevier, vol. 147(1), pages 1-42.

[8] Brzoza-Brzezina, M.\& Kolasa, M. \& Krzysztof, M., 2015. "Macroprudential policy and imbalances in the euro area," Journal of International Money and Finance, Elsevier, vol. 51(C), pages 137-154.

[9] Calza, A., Monacelli, T., Stracca, L., (2009), Housing Finance and Monetary Policy, Working Paper Series 1069, European Central Bank.

[10] Calvo, G., (1983), "Staggered prices in a utility-maximizing framework," Journal of Monetary Economics, 12 (3), 383-398

[11] Carrillo J. A. , Mendoza E. G., Nuguer V. and Roldán-Peña J. (2016) "Tight Money-Tight Credit: Tinbergen's Rule and Strategic Interaction in the Conduct of Monetary and Financial Policies", paper presented at the Conference "Rethinking inflation targeting. New directions for monetary policy",Oslo, Norges Bank, 8-9 September 2016. 
[12] Comunale, M. \& Hessel, J. (2014), "Current Account Imbalances in the Euro Area: Competitiveness or Financial Cycle?" DNB Working paper n.443.

[13] Comunale, M. (2017), "Synchronicity of cycles within countries and structural aspects", mimeo.

[14] Domeij, D., Flodén, M., (2006), "The Labor-Supply Elasticity and Borrowing Constraints: Why Estimates are Biased", Review of Economic Dynamics, 9, 242-262

[15] Drehmann, M., Borio, C., Gambacorta, L., Jiménez, G., Trucharte, C., (2010), "Countercyclical capital buffers: exploring options", BIS Working Papers, 317

[16] Ehrmann, M. and Ziegelmeyer, M. (2014), "Household risk management and actual mortgage choice in the euro area", Working Paper Series 1631, European Central Bank.

[17] Errit G. and Uuskula L. (2014), "Euro area monetary policy transmission in Estonia". Baltic Journal of Economics, 14(1-2):55-77

[18] European Central Bank, (2009), "Housing Finance in the Euro Area", Structural Issue Report, ECB, 2009.

[19] European Central Bank, (2016), "Macroprudential Bulletin 1/2016", ECB, 2016.

[20] Funke, M., Paetz, M., (2012), "A DSGE-Based Assessment of Nonlinear Loan-to-Value Policies: Evidence from Hong Kong ", BOFIT Discussion Paper No. 11/2012.

[21] Galati, G. and R. Moessner, (2011), "Macroprudential policy - a literature review", BIS Working Papers No 337 .

[22] Gelain, P., Lansing, K., Mendicino, C., (2013), "House Prices, Credit Growth, and Excess Volatility: Implications for Monetary and Macroprudential Policy", International Journal of Central Banking, $9(2)$

[23] Georgiadis, G. (2015), "Examining asymmetries in the transmission of monetary policy in the Euro Area: evidence from a mixed cross-section global VAR model". European Economic Review, 75:195-215

[24] Gilchrist, S., Hairault, J., Kempf, H., (2002), "Monetary Policy and the Financial Accelerator in a Monetary Union ", Working Paper Series 1175, European Central Bank. 
[25] Gruss, B., Sgherri, S., (2009), "The Volatility Costs of Procyclical Lending Standards: An Assessment Using a DSGE Model ", IMF Working Paper, 09/35.

[26] Huber, S. (2016), "Housing booms and busts: convergence and divergence in OECD countries", mimeo.

[27] Iacoviello, M., (2005), "House Prices, Borrowing Constraints and Monetary Policy in the Business Cycle", American Economic Review, 95 (3), 739-764

[28] Iacoviello, M., (2013), "Financial Business Cycles", Mimeo, Federal Reserve Board

[29] Iacoviello, M., Neri, S., (2010), "Housing Market Spillovers: Evidence from an estimated DSGE Model", American Economic Journal: Macroeconomics, American Economic Association, 2 (2), $125-64$

[30] Iacoviello, M., Smets, F., (2006), "House Prices and the Transmission Mechanism in the Euro Area: Theory and Evidence from a Monetary Union Model ", mimeo

[31] IMF, (2008), World Economic Outlook April 2008, International Monetary Fund.

[32] IMF, (2011), World Economic Outlook April 2011, International Monetary Fund.

[33] Kannan, P., Rabanal, P., Scott, A., (2012), "Monetary and Macroprudential Policy Rules in a Model with House Price Booms", The B.E. Journal of Macroeconomics, Contributions, 12 (1)

[34] Karmaziene, E., Varanauskiene, J., (2014), "Selection of Short-Term Fixed Interest Rate Mortgages in an Emerging Market: The Case of Lithuania", Bank of Lithuania Working Paper 16/2014

[35] Kydland, F., Prescott, E., (1982). "Time to Build and Aggregate Fluctuations", Econometrica 50, (6), 1345-1370

[36] Lambertini, L., Mendicino, C., Punzi, M., (2013), "Leaning against boom-bust cycles in credit and housing prices", Journal of Economic Dynamics and Control, 37 (8)

[37] Maclennan, D., Muellbauer, J., Stephens, M., (1998), "Asymmetries in Housing and Financial Market Institutions and EMU", Oxford Review of Economic Policy, 4 (3)

[38] Matkėnaitè, S., Ramanauskas, T. and Reichenbachas, T. (2016), "Paskolos ir užstato vertės santykio ribojimo Lietuvoje ekonominiai aspektai ", Teminiu Straipsniu Serija, 2016 n.9 (in Lithuanian), Bank of Lithuania. 
[39] McCallum, B., (2001), "Should Monetary Policy Respond Strongly To Output Gaps?," American Economic Review, 91(2), 258-262

[40] Mendicino, C., Pescatori, A., (2007), Credit Frictions, Housing Prices and Optimal Monetary Policy Rules, mimeo.

[41] Mink, M., J. Jacobs and J. de Haan (2012), "Measuring coherence of output gaps with an application to the euro area", Oxford Economic Papers 64: 217-236.

[42] Monacelli, T., (2006), "Optimal Monetary Policy with Collateralized Household Debt and Borrowing Constraint," in conference proceedings "Monetary Policy and Asset Prices" edited by J. Campbell.

[43] Monacelli, T., (2009), "New Keynesian Models, Durable Goods, and Collateral Constraints," Journal of Monetary Economics 56, 242-254

[44] Pedersen, J. (2015) "The Danish Natural Real Rate of Interest and Secular Stagnation", Working paper no 94, 2015, Danmarks Nationalbank.

[45] Quint, D. and Rabanal, P. (2014) "Monetary and Macroprudential Policy in an Estimated DSGE Model of the Euro Area", International Journal of Central Banking, 10, 169-236.

[46] Rubio, M., (2011), "Fixed- and Variable-Rate Mortgages, Business Cycles, and Monetary Policy," Journal of Money, Credit and Banking, 43 (4), 657-688

[47] Rubio, M., (2014), "Housing Market Heterogeneity in a Monetary Union," Journal of International Money and Finance, 40

[48] Rubio, M., Carrasco-Gallego, J.A., (2013), "Macroprudential Measures, Housing Markets, and Monetary Policy," Moneda y Credito, 235

[49] Rubio, M., Carrasco-Gallego, J.A., (2014), "Macroprudential and Monetary Policies: Implications for Financial Stability and Welfare", Journal of Banking and Finance, 49, 326-336.

[50] Rubio, M. and Carrasco-Gallego, J.A. (2015), "Macroprudential and Monetary Policy Rules: a Welfare Analysis," Manchester School, University of Manchester, vol. 83(2), 127-152

[51] Rubio, M., Comunale, M. (2017), "Lithuania in the Euro Area: Monetary Transmission and Macroprudential Policies," Eastern European Economics, 55:1, 29-49 
[52] Samarina, A., L. Zhang, D. Bezemer (2015), "Mortgages and credit cycle divergence in Eurozone economics", University of Groningen, Working Paper No. 15021.

[53] Schmitt-Grohe, S., Uribe, M., (2004), "Solving Dynamic General Equilibrium Models Using a Second-Order Approximation to the Policy Function," Journal of Economic Dynamics and Control, $28,755-775$

[54] Svensson, L.E.O. (2012) Comment on Michael Woodford, "Inflation Targeting and Financial Stability", Sveriges Riksbank Economic Review, 1, 33-39.

[55] Svensson, L.E.O. (2014) "Inflation Targeting and "Leaning against the Wind"", International Journal of Central Banking, 10, 103-114.

[56] Svensson, L.E.O. (2015) "Monetary Policy and Macroprudential Policy: Different and Separate", Tech. rep., Stockholm School of Economics and IMF.

[57] Stakènas J. and Stasiukynaitè R. (2016), "Monetary policy transmission: the case of Lithuania", Working Paper Series No. 24/2016, Bank of Lithuania.

[58] Task Force of the Monetary Policy Committee of the European System of Central Banks, (2009), "Housing Finance in the Euro Area", ECB Occasional Paper Series, 101

[59] Taylor, J. B. and Wieland, V., (2016). "Finding the Equilibrium Real Interest Rate in a Fog of Policy Deviations," CEPR Discussion Papers 11264, C.E.P.R. Discussion Papers.

[60] Tinbergen, J. (1952) On the Theory of Economic Policy. Amsterdam: North Holland Publishing Company.

[61] Yellen, J. (2014) "Monetary Policy and Financial Stability", Tech. rep., Board of Goverments of the Federal Reserve System. 


\section{Appendix}

Table A.1. Housing and mortgage markets in the EA19

$\begin{array}{rrrrrr} & \text { Average LTV } & \text { Max LTV } & \text { Rates } & \text { HH debt/GDP } & \text { NFCs debt/GDP } \\ \text { AT } & 65 & & \text { V } & 52 & 126 \\ \text { BE } & 83 & 100 & \text { F } & 59 & 166 \\ \text { CY } & 80 & \mathbf{7 5} & \text { V } & 142 & 354 \\ \text { DE } & 67 & 80 & \text { F } & 54 & 99 \\ \text { EE } & 71 & \mathbf{8 7 . 5} & \text { V } & 42 & 117 \\ \text { ES } & 70 & 100 & \text { V } & 72 & 154 \\ \text { FI } & 75 & 80 & \text { V } & 71 & 156 \\ \text { FR } & 67 & 100 & \text { F } & 65 & 144 \\ \text { GR } & 73 & & \text { V } & 69 & 126 \\ \text { IE } & 66 & \mathbf{8 5} & \text { F } & 62 & 303 \\ \text { IT } & 55 & 80 & \text { F } & 47 & 117 \\ \text { LT } & \mathbf{7 8} & \mathbf{8 5} & \text { V } & \mathbf{3 4} & \mathbf{5 5} \\ \text { LU } & 87 & & \text { F } & 58 & 343 \\ \text { LV } & 95 & \mathbf{9 5} & \text { V } & 26 & 89 \\ \text { MT } & 63 & \mathbf{7 0} & \text { V } & 66 & 132 \\ \text { NL } & 90 & \mathbf{1 0 2} & \text { F } & 122 & 229 \\ \text { PT } & 83 & 90 & \text { V } & 80 & 182 \\ \text { SI } & 65 & & \text { V } & 31 & 87 \\ \text { SK } & 70 & \mathbf{9 5} & \text { F } & 37 & 81\end{array}$

Note: The data are taken from $\operatorname{ECB}(2016,2009)$, Huber (2016) and $\operatorname{IMF}(2008,2011)$. They are integrated with information coming from national sources in the case of Lithuania, Estonia, Slovenia, Greece and Hungary. For the rates, the data concern new loans and are from ECB SDW (data up to 2016). For the rates, V means that the majority of loans are at variable rates while $\mathrm{F}$ stands for fixed. The data on household (HH) or NFCs debt/GDP are from Eurostat and they are for 2015. The Max LTV is the regulatory LTV if the value is in bold. These are averaged if concern different types of loans. ${ }^{47}$

\footnotetext{
${ }^{47}$ We are very thankful to Lorenzo Isgrò for the data on the rates and to Dmitry Kulikov for the Estonian data. The max LTV data in case of AT, GR, LU and SI are not available.
} 